\title{
REHABILITASI EKOSISTEM HUTAN MANGROVE DAN PELESTARIAN LINGKUNGAN DARI PENCEMARAN SAMPAH DI DESA SIMAU MELALUI PENGABDIAN KEPADA MASYARAKAT
}

\section{Mangrove Forest Ecosystem Rehabilitation and Environmental Preservation from Waste Pollution in Simau Village Through Community Service}

\author{
Boyke Raymond Toisuta ${ }^{1 *}$, Ontje F.W. Tutupary ${ }^{1}$, Alberth I. Pical ${ }^{1}$, Loana J. Totoda ${ }^{1}$ \\ ${ }^{1)}$ Program Studi Manajemen Sumberdaya Perairan, Fakultas Ilmu Alam dan Teknologi \\ Rekayasa, Universitas Halmahera
}

*Korespondensi : boytoisuta@ymail.com

\begin{abstract}
ABSTRAK
Kerusakan hutan mangrove di wilayah pesisir desa Simau sebagian besar disebabkan oleh terjadinya penebangan hutan mangrove untuk kayu bakar, bahan bangunan, dan, masyarakat juga memanfaatkan areal sekitar hutan mangrove untuk tempat pemukiman dalam pencarian telur burung mamoa. Selain itu juga keberadaan sampah dilokasi tidak bisa dihindari karena semakin menumpuk sehingga dapat menimbulkan pencemaran sumber penyakit. Berdasarkan uraian tersebut maka dipandang perlu membangun Desa Simau melalui kegiatan pengabdian kepada masyarakat dalam rangka merehabilitasi hutan mangrove dan menjaga kebersihan lingkungan dipesisir dari pencemaran sampah. Tujuan kegiatan ini adalah merehabilitasi hutan mangrove untuk menjaga kelangsungan hidup ekosistemnya dan memulihkan kembali hutan mangrove yang rusak agar dapat kembali memberikan fungsinya bagi kesejahteraan manusia dan mendukung pembangunan wilayah pesisir serta menjaga kelestarian lingkungan pesisir dari pencemaran sampah yang berasal dari aktivitas masyarakat. Program pengabdian dilaksanakan melalui dialog bersama dan kegiatan demonstrasi yaitu kegiatan pembibitan dan penanaman 1000 anakan mangrove dan 100 anakan ketapang pada lokasi yang telah rusak, kemudian dilanjutkan dengan pembersihan lokasi pesisir dari pencemaran berbagai jenis sampah. Tercapainya tujuan ini karena dihadiri oleh 147 orang peserta yang menunjukkan antusiasme sangat besar terhadap program pengabdian ini. Kemudian keberhasilan kerjasama peserta dalam kegiatan pengabdian dapat dikatakan sangat baik karena didukung penggunaan metode dialog bersama dan demonstrasi untuk meningkatkan antusiasme para peserta. Keberhasilan ini diukur dari keempat komponen yaitu keberhasilan target peserta, ketercapaian tujuan, ketercapaian materi, dan kerjasama dalam pengabdian.
\end{abstract}

Kata Kunci: Ekosistem Hutan Mangrove, Rehabilitasi, Sampah, Simau

\begin{abstract}
Destruction of mangrove forests in coastal areas is largely caused by the cutting down of mangrove forests for firewood, building materials, and utilizes the area of the mangrove forest for settlement of mamoa eggs collector. In addition, the presence of garbage in the location cannot be avoided. Based on this description, it is necessary to develop Simau Village through community service activities in the context of rehabilitating mangrove forests and maintaining environmental cleanliness. The purpose of this activity is to rehabilitate
\end{abstract}


mangrove forests to maintain the viability of their ecosystems and to restore damaged mangrove forests so that they can provide their functions for human welfare and support the development of coastal areas as well as preserving the coastal environment from pollution. Service program is carried out through joint dialogue and demonstration activities, namely nursery and planting of 1000 mangrove and 100 ketapap at damaged locations. The program followed by cleaning up coastal locations from various types of trash pollution. The program was attended by 147 participants who showed great enthusiasm. The collaboration in community service program was very good because it is supported by joint dialogue methods and demonstration methods to increase the enthusiasm of the participants. These successes are measured from the four components such as success of participant target, achievement of objectives, achievement of material, and cooperation in service.

Keywords: Mangrove Forest Ecosystem, Rehabilitation, Simau, Waste

\section{PENDAHULUAN}

Ekosistem mangrove merupakan ekosistem di wilayah pesisir yang mempunyai peran penting mendukung produktivitas perikanan. Disamping itu juga merupakan perlindung pantai secara alami mengurangi resiko dari bahaya tsunami dan juga merupakan habitat dari beberapa jenis satwa liar. Ekosistem mangrove juga merupakan tempat bagi berbagai biota melakukan pemijahan (Spawning Ground), tempat pengasuhan (Nursery Ground) dan tempat mencari makanan (Feeding Ground).

Hutan mangrove di Desa Simau merupakan mangrove tipe semi tertutup dimana tidak berhubungan langsung dengan perairan laut secara langsung dan terlindung dari hantaman ombak. dan tersebar pada muara dan aliran sungai. Letaknya berada di bagian pesisir timur hingga utara Desa Simau Kecamatan Galela, Kabupaten Halmahera Utara, Propinsi Maluku Utara. Komunitas mangrove di Desa Simau dimanfaatkan sebagai sumber mata pencarian dan berbagai aktivitas masyarakat.

Hutan mangrove di Desa Simau memiliki luas komunitas mangrove sebesar 5.465,6 ha dengan panjang 8,54 $\mathrm{km}$ dan lebar rata-rata $0,64 \mathrm{~km}$. Hasil identifikasi jenis mangrove yang ditemukan pada Desa
Simau sebanyak 15 spesies yaitu Aegiceras corniculatum, Avicennia lanata, Avicennia marina, Bruguiera cylindrica, Bruguiera gymnorrhiza, Bruguiera sexangula, Ceriops decandra, Ceriops tagal, Heritiera littoralis, Nypa fruticans, Rhizophora apiculata, Rhizophora mucronata, Rhizophora stylosa, Sonneratia alba dan Sonneratia caseolaris.

Persepsi masyarakat Desa Simau tentang kondisi hutan mangrove dimana pengrusakan hutan mangrove di wilayah pesisir sebagian besar disebabkan oleh terjadinya penebangan hutan mangrove untuk kayu bakar, bahan bangunan, dan kebutuhan lainnya. Penebangan hutan mangrove tersebut mengakibatkan terjadinya perubahan keseimbangan fungsi hutan mangrove. Biasanya penebangan hutan mangrove dilakukan oleh sebagian besar masyarakat sendiri. Disamping itu, masyarakat juga memanfaatkan areal sekitar hutan mangrove untuk tempat pemukiman dalam pencarian telur burung mamoa, karena lokasi tersebut merupakan habitat bertelurnya burung mamoa.

Selain itu keberadaan sampah dilokasi tidak bisa dihindari karena semakin menumpuk sehingga dapat menimbulkan pencemaran sumber penyakit dan merusak keindahan alam disekitarnya serta menurunkan nilai ekonomi sebagai 
ekowita bagi wisatawan atau masyarakat yang datang berkunjung.

Berdasarkan uraian diatas maka dipandang perlu membangun Desa Simau melalui kegiatan pengabdian kepada masyarakat dalam rangka merehabilitasi hutan mangrove dan menjaga kebersihan lingkungan dipesisir dari pencemaran sampah

Beberapa permasalahan yang teridentifikasi di lokasi pengabdian Desa Simau Kabupaten Halmahera Utara, antara lain:

a. Kurangnya kesadaran masyarakat tentang fungsi sumberdaya hutan mangrove sebagai upaya pelestarian masih sangat rendah.

b. Peningkatan volume sampah plastik seiring dengan keberadaan masyarakat dilokasi hutan mangrove tersebut dimana mereka membuang sampah sembarangan tempat maupun sampai kedalam dasar perairannya.

c. Rendahnya kualitas sumberdaya manusia dalam mengatasi ancaman abrasi air laut yang sewaktu-waktu mengikis pasir tempatnya habitat biota laut.

Tujuan dilakukannya kegiatan pengabdian kepada masyarakat ini adalah dapat merehabilitasi hutan mangrove untuk menjaga kelangsungan hidup ekosistemnya dan memulihkan kembali hutan mangrove yang rusak agar dapat kembali memberikan fungsinya bagi kesejahteraan manusia dan mendukung pembangunan wilayah pesisir, serta menjaga kelestarian lingkungan pesisir dari pencemaran sampah yang berasal dari aktivitas masyarakat

Manfaat yang diharapkan dari kegiatan pengabdian kepada masyarakat adalah sebagai berikut:

a. Sebagai wahana untuk meningkatkan pengetahuan dan wawasan khalayak sasaran serta kesadaran masyarakat dalam melestarikan ekosistem hutan mangrove. b. Meningkatkan kesadaran masyarakat yang datang kelokasi hutan mangrove tentang pentingnya menjaga kebersihan lingkungan disekitarnya dengan membuang sampah pada tempatnya sehingga tidak terjadi penumpukan sampah dilokasi hutan mangrove.

c. Sebagai komunkasi antara masyarakat dengan dengan perguruan tinggi, mencari solusi dengan tujuan untuk melestarikan hutan mangrove.

\section{METODOLOGI}

\section{Waktu dan Lokasi}

Waktu kegiatan pengabdian dilaksanakan pada 14 - 16 Februari 2019, yang berlokasi di Desa Simau, Kecamatan Galela, Kabupaten Halmahera Utara, Provinsi Maluku Utara.

\section{Alat Dan Bahan}

Alat dan bahan yang digunakan dalam kegiatan pengabdian ini sebagai berikut :

a. 1000 Anakan Bibit Mangrove

b. 100 Anakan Bibit Ketapang

c. Softcopy materi

d. Kamera Digital

e. Drone

f. Parang

g. Sapu

h. Karung Plastik

i. Peralatan Diving

j. Alat / Bahan Pendukung Lainnya

\section{Khalayak Sasaran}

Kegiatan pengabdian ini dilaksanakan oleh kerjasama Program Studi Manajemen Sumberdaya Perairan dengan CEPF Universitas Halmahera yang disponsori oleh Burung Indonesia Jakarta.

Khalayak sasaran kegiatan pengabdian ini adalah sebagai berikut:

a. Intansi Pemerintah Kabupaten Halmahera Utara yang terdiri dari: Pemerintahan Kecamatan Galela dan BKSDA Resort Kabupaten Halmahera 
Utara yang diundang sebanyak 10 orang.

b. Tim CEPF Uniera dan Tim Burung Indonesia yang diundang sebanyak 7 orang.

c. Pemerintahan dan Masyarakat Desa Simau yang terdiri dari: Ketua BPD Simau, Kades Simau, Tokoh Masyarakat, Pemuda dan Pemudi Simau, serta Komunitas Selabia yang diundang sebanyak 50 orang.

d. Civitas Akademik Universitas Halmahera yang terdiri dari Dosen dan Mahasiswa Program Studi Manajemen Sumberdaya Perairan yang diundang sebanyak 30 orang.

e. Mahasiswa Halmahera Pencinta Alam Tobelo, yang diundang sebanyak 10 orang.

f. Para Siswa SMA dan SMP Di Kecamatan Galela yang terdiri dari SMA Negeri 2 Halmahera Utara dan SMP Madrasah Aliyah Muhammadiyah yang diundang sebanyak 40 orang (20 orang siswa SMA dan 20 orang siswa SMP)

\section{Metode Pengabdian}

Metode kegiatan pengabdian yang digunakan, antara lain:

\section{a. Dialog Bersama}

Metode dialog dipilih untuk menyampaikan konsep tentang fungsi dan peran dari ekosistem hutan mangrove serta kegiatan rehabilitas hutan mangrove. Kemudian dilanjutkan dengan sesi Tanyajawab antara Tim pengabdian dan peserta kegiatan pengabdian.

\section{b. Demonstrasi}

Metode demonstrasi ini dilakukan oleh seluruh peserta yang hadir dilokasi pengabdian dengan membentuk dua kelompok dengan memiliki tugasnya masing-masing yaitu:

- Kelompok Pertama, dengan tugasnya yaitu melakuan kegiatan pembibitan 1000 anakan mangrove dan 100 anakan ketapang.
- Kelompok Kedua, dengan tugasnya yaitu membersihkan setiap lokasi hutan mangrove dari segala jenis sampah.

Setelah tugas dari masing-masing kelompok telah selesai, kemudian secara bersama-sama melakukan proses penanaman 1000 anakan mangrove dan 100 anakan ketapang disetiap daerah pesisir Desa Simau yang lokasinya mengalami kerusakan.

\section{Langkah-Langkah Pengabdian}

Langkah-langkah kegiatan dalam pengabdian ini melalui tahapan-tahapan berikut ini:

a. Dialog bersama tentang ekosistem dan rehabilitas hutan mangrove serta masalah sampah.

b. Diskusi mengenai hal-hal yang berkaitan dengan hutan mangrove dan sampah.

c. Demonstrasi proses pembibitan anakan mangrove dan ketapang, kemudian pembersihan lokasi dari sampah, selanjutnya penanaman anakan mangrove dan ketapang disetiap daerah pesisir.

\section{Faktor Pendukung dan Penghambat}

Berdasarkan evaluasi pelaksanaan kegiatan, dapat diidentifikasi faktor-faktor pendukung dan penghambat dalam pelaksanaan program pengabdian ini, antara lain:

\section{a. Faktor Pendukung}

- Instansi Pemerintah Kabupaten Halmahera Utara yang mendukung dan ikut terlibat bersama dalam kegiatan pengabdian ini.

- Rektor Universitas Halmahera yang mendukung kegiatan pengabdian kepada masyarakat ini.

- Dekan Fakultas Ilmu Alam dan Teknologi Rekayasa yang ikut mendukung dan terlibat bersama dilokasi serta memberikan surat tugas kepada Program Studi Manajemen Sumberdaya Perairan dalam 
melaksanakan pengabdian kepada masyarakat ini.

- Tim CEPF Uniera dan Burung Indonesia yang bersedia kerjasama dalam memfasilitasi kegiatan pengabdian kepada masyarakat ini.

- Pemerintah dan Masyarakat Desa Simau yang bersedia berkerjasama dan mendukung pelaksanaan kegiatan pengabdian kepada masyarakat ini.

- Civitas Akademik Universitas Halmahera yang terdiri dari Dosen dan Mahasiswa Program Studi Manajemen Sumberdaya Perairan yang turut mengambil bagian dalam membantu pelaksanaan pengabdian ini.

- Mahasiswa Halmahera Pencinta Alam yang turut memberikan tenaga untuk kegiatan pengabdian kepada masyarakat ini.

- Para Siswa dari SMA Negeri 2 Halmahera Utara dan SMP Madrasah Aliyah Muhammadiyah yang ikut melaksanakan kegiatan pengabdian kepada masyarakat ini.

\section{b. Faktor Penghambat}

- Kurangnya peralatan berbasis teknologi dalam menangani masalah sampah didalam pengabdian ini, karena mengingat bahwa luasan area yang begitu besar

\section{HASIL DAN PEMBAHASAN}

\section{Ekosistem Hutan Mangrove}

Mangrove hidup di daerah level pasang naik tertinggi (maximum spring level) sampai level di sekitar atau di atas permukaan laut rata-rata (mean sea level). Hampir $75 \%$ tumbuhan mangrove hidup. Dahuri (2003) menyatakan bahwa ada tiga parameter lingkungan yang menentukan kelangsungan hidup dan pertumbuhan mangrove yakni: suplai air tawar dan salinitas, pasokan nutrient, stabilitas substrat secara ekologis hutan mangrove telah dikenal mempunyai banyak fungsi dalam kehidupan manusia baik secara langsung maupun tidak langsung.
Selanjutnya dikatakan Agil et al. (2014) bahwa ekosistem mangrove memiliki beberapa peranan penting diantaranya adalah: (1) sebagai tempat pemijahan (Nursery Ground), (2) tempat mencari (Feeding Ground), dan (3) tempat perlindungan (Shelter) beberapa organisme perairan, satwa liar, primata, serangga, burung, reptil dan amphibi.

Ekosistem mangrove bagi sumberdaya ikan dan udang berfungsi sebagai tempat mencari makan, memijah, memelihara juvenil dan berkembang biak. Bagi fungsi ekologi sebagai penghasil sejumlah detritus dan perangkap sedimen. Hutan mangrove merupakan habitat berbagai jenis satwa baik sebagai habitat pokok maupun sebagai habitat sementara. Bagi fungsi ekonomis dapat bermanfaat sebagai sumber penghasil kayu bangunan, bahan baku pulp dan kertas, kayu bakar, bahan arang, alat tangkap ikan dan sumber bahan lain seperti tannin dan pewarna. Arang dari jenis Rhizophora spp mempunyai nilai panas yang tinggi dan asapnya sedikit. Mangrove juga mempunyai peran penting sebagai pelindung pantai dari hempasan gelombang air laut.

Dinamika ekologi perairan pesisir akan mempengaruhi produktivitas perikanan di lepas pantai. Indrajaya (1992) menyatakan bahwa pengubahan fungsi hutan mangrove menjadi fungsi lain secara tidak wajar akan mengakibatkan timbulnya keadaan yang tidak sesuai dengan kaifah pembangunan yang berkelanjutan. Alih fungsi hutan mangrove saat ini banyak digunakan untuk pembukaan areal tambak baru, tempat rekreasi, pelabuhan dan lain-lain ternyata menurut para ahli dan pemerhati lingkungan hidup berpendapat bahwa dari segi ekonomi makro, alih fungsi hutan mangrove menjadi areal tambak tidak akan memberikan hasil yang lebih besar jika dibandingkan dengan membiarkan ekosistem mangrove sebagai habitat biota secara alamiah. Alih fungsi mangrove maka akan merusak siklus rantai makanan bagi seluruh biota ekosositem mangrove 
yang juga berkaitan dengan biota yang di depannya yakni padang lamun dan terumbu karang, karena ada interaksi yang sangat kuat dari ketiga ekosistem tersebut. Apabila fungsi-fungsi hutan mangrove akibat alih fungsi maka otomatis akan akan mengganggu bahkan merusak kedua ekosisitem lainnya.

Bengen (2000) menyatakan bahwa dengan pertumbuhan penduduk yang tinggi dan pesatnya kegiatan pembangunan di pesisir bagi berbagai peruntukan (pemukiman, perikanan, pelabuhan, dan lainnya), tekanan ekologis terhadap ekosistem pesisir, khususnya ekosistem hutan mangrove, semakin meningkat pula. Meningkatnya tekanan ini tentunya berdampak terhadap kerusakan ekosistem hutan mangrove itu sendiri baik secara langsung (misalnya kegiatan penebangan atau konversi lahan) maupun tak langsung (misalnya pencemaran oleh limbah berbagai kegiatan pembangunan).

\section{Pengelolaan Ekosistem Hutan Mangrove}

Pengelolaan mangrove didasarkan atas tiga tahapan utama (isu-isu). Isu-isu tersebut adalah :

\section{a. Isu Ekologi dan Isu Sosial Ekonomi}

Isu ekologi meliputi dampak ekologis intervensi manusia terhadap ekosistem mangrove. Berbagai dampak kegiatan manusia terhadap ekosistem mangrove harus diidentifikasi, baik yang telah terjadi maupun yang akan terjadi di kemudian hari. Adapun isu sosial ekonomi mencakup aspek kebiasaan manusia (terutama masyarakat sekitar hutan mangrove) dalam memanfaatkan sumberdaya mangrove. Begitu pula kegiatan industri, tambak, perikanan tangkap, pembuangan limbah, dan sebagainya di sekitar hutan mangrove harus diidentifikasi dengan baik.

\section{b. Isu Kelembagaan dan Perangkat Hukum \\ Di samping lembaga-lembaga lain,} Departemen Pertanian dan Kehutanan, serta Departemen Kelautan dan Perikanan, merupakan lembaga yang sangat berkompeten dalam pengelolaan mangrove. Koordinasi antar instansi yang terkait dengan pengelolaan mangrove adalah mendesak untuk dilakukan saat ini. Aspek perangkat hukum adalah peraturan dan undang-undang yang terkait dengan pengelolaan mangrove.

Sudah cukup banyak undang-undang dan peraturan yang dibuat oleh pemerintah dan instansi-instansi yang terkait dalam pengelolaan mangrove. Yang diperlukan sekarang ini adalah penegakan hukum atas pelanggaran terhadap perangkat hukum tersebut.

\section{c. Strategi dan Pelaksanaan Rencana}

Dalam kerangka pengelolaan dan pelestarian mangrove, terdapat dua konsep utama yang dapat diterapkan. Kedua konsep tersebut pada dasarnya memberikan legitimasi dan pengertian bahwa mangrove sangat memerlukan pengelolaan dan perlindungan agar dapat tetap lestari. Kedua kosep tersebut adalah perlindungan hutan mangrove dan rehabilitasi hutan mangrove (Bengen, 2001).

Salah satu cara yang dapat dilakukan dalam rangka perlindungan terhadap keberadaan hutan mangrove adalah dengan menunjuk suatu kawasan hutan mangrove untuk dijadikan kawasan konservasi, dan sebagai bentuk sabuk hijau di sepanjang pantai dan tepi sungai. Dalam konteks di atas, berdasarkan karakteristik lingkungan, manfaat dan fungsinya, status pengelolaan ekosistem mangrove dengan didasarkan data Tataguna Hutan Kesepakatan (Santoso, 2000) terdiri atas:

- Kawasan Lindung (hutan, cagar alam, suaka margasatwa, taman nasional, taman laut, taman hutan raya, cagar biosfir).

- Kawasan Budidaya (hutan produksi, areal penggunaan lain).

Perlu diingat di sini bahwa wilayah ekosistem mangrove selain terdapat kawasan hutan mangrove juga terdapat 
areal atau lahan yang bukan kawasan hutan, biasanya status hutan ini dikelola oleh masyarakat (pemilik lahan) yang dipergunakan untuk budidaya perikanan, pertanian, dan sebagainya. Saat ini dikembangkan suatu pola pengawasan pengelolaan ekosistem mangrove partisipatif yang melibatkan masyarakat.

Ide ini dikembangkan atas dasar pemikiran bahwa masyarakat pesisir yang relatif miskin harus dilibatkan dalam pengelolaan mangrove dengan cara diberdayakan, baik kemampuannya (ilmu) maupun ekonominya.

Pola pengawasan pengelolaan ekosistem mangrove yang dikembangkan adalah pola partisipatif meliputi : komponen yang diawasi, sosialisasi dan transparansi kebijakan, institusi formal yang mengawasi, para pihak yang terlibat dalam pengawasan, mekanisme pengawasan, serta insentif dan sanksi (Santoso, 2000)

\section{Ancaman Sampah Diwilayah Pesisir}

Secara fakta Indonesia merupakan negara nomor dua di dunia dengan produksi sampah terbanyak di lautan karena pada setiap tahun sebanyak 1,29 juta ton sampah dibuang ke wilayah pesisir, sungai dan bermuara di perairan sehingga hal ini dapat memberikan ancaman berdampak buruk terhadap ekosistem biota maupun tanaman dilingkungan perairan. Dengan ancaman sampah yang terus meningkat maka Pemerintah Indonesia melakukan upaya yang melalui penanganan yang terintegrasi, baik dari tataran kebijakan hingga pengawasan implementasi dan kebijakan penanganan sampah (Widyatmoko, 2002).

Sampah hingga kini masih menjadi persoalan serius dan menjadi ancaman bagi Indonesia dan juga negara lain di dunia. Sampah tidak hanya dapat dijumpai di wilayah darat saja, tapi juga sudah menyebarluas ke wilayah pesisir dan perairan yang luasnya mencapai $2 / 3$ dari total luas Indonesia. Sampah yang berasal dari daratan dan dibuang ke pesisir pantai jumlahnya mencapai $80 \%$ dari total sampah yang ada di perairan, kemudian sampah-sampah tersebut terbawa sampai ke lautan. Terbawanya sampah ini ke lautan disebabkan oleh pengelolaan sampah yang kurang efektif dalam menangani sampah (Widyatmoko, 2002).

Secara umumnya sampah di wilayah pesisir dan perairan cukup membuat masyarakat khawatir dengan banyaknya sampah yang merusak ekosistem perairan terutama biotan dan tanaman di daerah perairan dimana merupakan tempat para nelayan mencari ikan dan tempat wisatawan.

Berbagai masalah dan tantangan yang dihadapi saat ini dalam mengelola sampah harus dipecahkan bersama dalam mencari inovatif, kebijakan lokal dan nasional, kemitraan swasta, publik, dan pendidikan untuk perubahan perilaku masyarakat agar berperan aktif memerangi sampah yang ada berada di wilayah pesisir maupun perairan. Pengelolaan sampah merupakan kegiatan untuk menangani sampah sejak ditimbulkan sampai dengan pembuangan akhir (Sejati, 2009).

\section{Hasil Pengabdian}

Adapun garis besar hasil kegiatan pengabdian kepada masyarakat adalah sebagai berikut:

a. Langkah Awal Pengabdian

Langkah awal dari Tim Pengabdian Program Studi Manajemen Sumberdaya Perairan yaitu :

- Penyampaian gagasan pelaksanaan pengabdian kepada CEPF Uniera dan Burung Indonesia untuk berkerjasama dalam rangka dapat memfasilitasi kegiatan pengabdian ini dengan tujuan untuk melestarikan ekosistem hutan mangrove dan menjaga kebersihan lingkungan dari pencemaran sampah.

- Penyampaian permohonan ijin kepada Pemerintah Desa Simau dalam melaksanakan kegiatan pengabdian dilokasi pesisir. 
- Penyampaian program kegiatan pengabdian Program Studi kepada Dekan Fakultas Ilmu Alam dan Teknologi Rekayasa untuk dapat memberikan Surat Tugas kepada Tim Pengabdian Program Studi Manajemen Sumberdaya Perairan dalam melaksanakan pengabdian kepada masyarakat.

- Menginformasikan serta mengundang seluruh civitas akademik baik Dosen dan Mahasiswa untuk turut mengambil bagian dalam melaksanakan kegiatan pengabdian ini khususnya Universitas Halmahera dan Politeknik Padamara Tobelo.

- Penyampaian gagasan sekaligus dukungan dari Instansi Pemerintah Kabupaten Halmahera Utara untuk sama-sama dalam melaksanakan kegiatan pengabdian di Desa Simau.

- Mensosialisasi kegiatan pengabdian ini di Sekolah, sekaligus mengundang para siswa untuk turut terlibat langsung dilokasi pengabdian.

\section{b. Hasil Pelaksanaan Pengabdian}

Hasil pelaksanaan kegiatan pengabdian kepada masyarakat sebagai berikut:

- Kegiatan pengabdian yan dilaksanakan di Desa Simau, Kecamatan Galela, Kabupaten Halmahera Utara telah dihadiri oleh 147 orang peserta atau undangan. Semua orang yang terlibat menunjukkan antusiasme sangat besar terhadap program pengabdian ini.

- Materi yang disampaikan dalam kegiatan pengabdian ini, berjalan dengan baik dan secara detil.
- Kerjasama seluruh peserta atau undangan dalam kegiatan pengabdian untuk merehabilitasi ekosistem hutan mangrove melalui kegiatan pembibitan dan penanaman 1000 anakan mangrove dan 100 anakan ketapang serta kebersihan dari segala pencemaran jenis sampah dapat dibersihkan disetiap lokasi pesisir berjalan dengan baik.

- Walaupun dengan keterbatasan alat dan bahan yang digunakan namun antusiasme peserta maupun undangan dalam melaksanakan program pengabdian dapat dikatakan berhasil karena mencapai tujuan yaitu melestarikan ekosistem hutan mangrove dan menjaga kebersihan lingkungan.

\section{c. Laporan Hasil Pengabdian}

Penyusunan laporan hasil pengabdian kepada masyarakat yang dilakukan secara tertulis dan telah dipertanggujawabkan kepada LPPM Universitas Halmahera.

\section{Pembahasan Pengabdian}

\section{a. Gambaran Umum Lokasi Pengabdian}

Desa Simau merupakan wilayah yang terletak di Kecamatan Galela, Kabupaten Halmahera Utara. Wilayah Desa Simau memiliki keadaan alamnya yang sangat menentukan potensi bagi penghidupan masyarakat lokal sebagai sumber mata pencaharian masyarakat. Dan yang sangat menarik dari wilayah tersebut adalah terdapat sebuah hutan mangrove yang luas, sehingga semakin menambah keindahan panorama alam disekitarnya. 


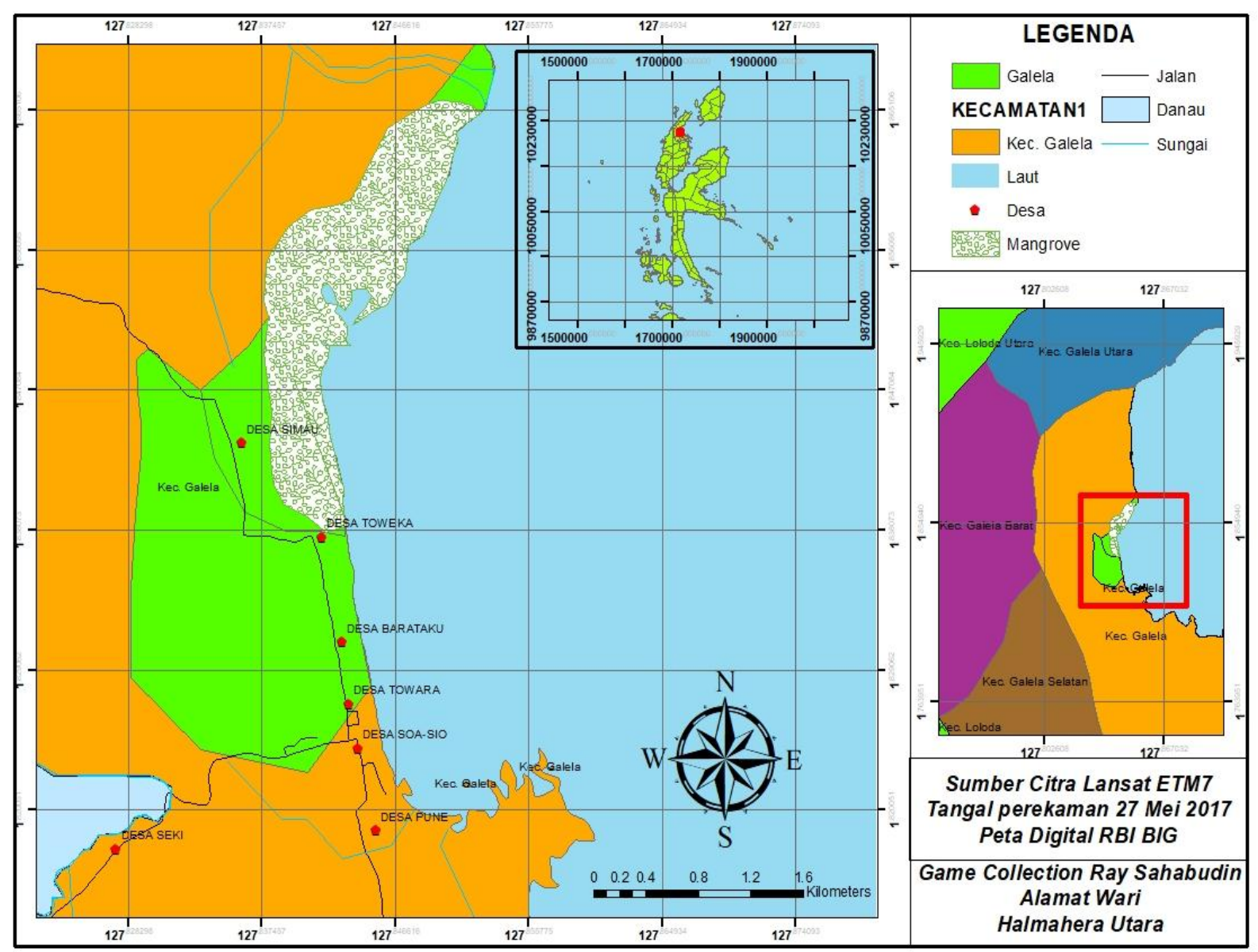

Gambar 1. Peta Desa Simau

Luasan sebaran jenis mangrove di Desa Simau sebesar 5.465,6 ha dengan jumlah hasil identifikasinya sebanyak 15 spesies mangrove. Jumlah jenis mangrove telah mengalami penurunan secara dratis akibat aktivitas manusia, karena penelitian sebelumnya yang dilakukan oleh Pical (2017), ditemukan ada sebanyak 24 spesies jenis mangrove yang berada di wilayah Tobelo. Perbandingan inidapat disimpulkan bahwa hutan mangrove telah terancam dan mengalami kerusakan akibat aktivitas manusia dan terbawa ombak saat menghantam lokasi tersebut.

Perubahan fisik lingkungan wilayah pesisir Desa Simau akibat aktivitas manusia sangat mempengaruhi lingkungan hutan mangrove diantaranya adalah terjadinya pertumbuhan penduduk, perubahan iklim dan dinamika pantai. Meningkatnya pertumbuhan penduduk setiap tahunnya dan sebagian hidup di wilayah pesisir dapat mengakibatkan meningkatnya aktivitas manusia di wilayah pesisir terutama dalam pemanfaatan sumberdaya alam dan ekosistem pesisir. Aktivitas manusia yang dilakukan baik didaratan maupun dilautan mendorong terjadinya perubahan lingkungan wilayah pesisir Desa Simau. Dahuri et al. (2001) menyatakan bahwa setiap perubahan bentang alam daratan dan dampak negatif lainnya seperti pencemaran, erosi dan perubahan secara drastis regim aliran air tawar yang terjadi di ekosistem daratan pada akhirnya akan berdampak terhadap ekosistem pesisir.

Seiring dengan meningkatnya pertumbuhan dan aktivitas penduduk Desa Simau, maka kebutuhan akan dimanfatkannya hutan mangrove semakin meningkat untuk dijadikan sebagai keperluan rumah tangganya yaitu 
sebagai lahan perikanan, pertanian dan pemukiman, serta penebangan untuk dijadikan kayu bakar dan bahan bangunan. Hal ini menyebabkan hutan mangrove tidak berfungsi dengan baik sehingga memberikan dampak negatif terhadap lingkungan wilayah pesisir Desa Simau.

\section{b. Program Pengabdian}

Pelaksanaan program pengabdian di wilayah pesisir Desa Simau, Kecamatan Galela, Kabupaten Halmahera Utara Desa dilakukan dengan tujuan untuk mengurangi ancaman terhadap ekosistem hutan mangrove. Program pengabdian ini dalam bentuk kegiatan rehabilitasi hutan mangrove dan menjaga kebersihan lingkungan dari berbagi jenis sampah dan sampai saat ini terus diupayakan, mengingat bahwa berubahnya komposisi tumbuhan; pohon-pohon mangrove akan digantikan oleh spesies-spesies yang nilai ekonominya rendah dan hutan mangrove yang ditebang ini tidak lagi berfungsi sebagai daerah mencari makan (feeding ground) dan daerah pengasuhan (nursery ground) yang optimal bagi bermacam ikan dan biota lainnya yang penting secara ekonomi. Peningkatan salinitas hutan (rawa) mangrove menyebabkan dominasi dari spesies-spesies yang lebih toleran terhadap air yang menjadi lebih asin; ikan dan biota lainnya mungkin tak dapat mentoleransi peningkatan salinitas, karena mereka lebih sensitif terhadap perubahan lingkungan. Kemudian menurunnya tingkat kesuburan hutan mangrove karena pasokan zat-zat hara melalui aliran air tawar berkurang sehingga dapat mengancam regenerasi stok-stok ikan dan biota lainnya di perairan lepas pantai yang memerlukan hutan (rawa) mangrove sebagai nursery ground larva dan/atau stadium muda ikan dan udang. Selain itu juga pencemaran laut oleh bahan-bahan pencemar yang sebelum hutan mangrove dikonversi dapat diikat oleh substrat hutan mangrove. Pendangkalan peraian pantai karena pengendapan sedimen yang sebelum hutan mangrove dikonversi mengendap di hutan mangrove. Intrusi garam melalui saluran-saluran alam yang bertahankan keberadaannya atau melalui saluran-saluran buatan manusia yang bermuara di laut. Erosi garis pantai yang sebelumnya ditumbuhi mangrove.

Penurunan kandungan oksigen terlarut dalam air, bahkan dapat terjadi keadaan anoksik dalam air sehingga bahan organik yang terdapat dalam sampah cair mengalami dekomposisi anaerobik yang antara lain menghasilkan hidrogen sulfida $\left(\mathrm{H}_{2} \mathrm{~S}\right)$ dan aminia $\left(\mathrm{NH}_{3}\right)$ yang keduanya merupakan racun bagi organisme hewani dalam air. Bau $\mathrm{H}_{2} \mathrm{~S}$ seperti telur busuk yang dapat dijadikan indikasi berlangsungnya dekomposisi anaerobik. Selanjutnya adanya kemungkinan terlapisnya pneumatofora dengan sampah padat yang akan mengakibatkan kematian pohon-pohon mangrove. Perembesan bahan-bahan pencemar dalam sampah padat yang kemudian larut dalam air ke perairan di sekitar pembuangan sampah.

Dengan demikian hal ini menjadi pertimbangan bagi Tim Pengabdian Program Studi Manajemen Sumberdaya Perairan untuk mencari solusi dalam melestarikan lingkungan hutan mangrove dan lokasi perairan sehingga tidak rusak dan mencemari lingkungan, melainkan dapat mampu memberikan keuntungan untuk meningkatkan nilai ekonomis dan keindahan alamnya tetap lestari.

Program pengabdian yang dilakukan terbagi menjadi tiga tahapan sebagai berikut:

- Tahapan Observasi

- Tahapan Dialog Bersama

- Tahapan Demonstrasi

\section{- Tahapan Observasi}

Pada tahap awal program pengabdian, dimana melakukan observasi pada lokasi yang mengalami tingkat kerusakan dan tercemar oleh berbagai jenis sampah yang diakibatkan aktivitas masyarakat. 


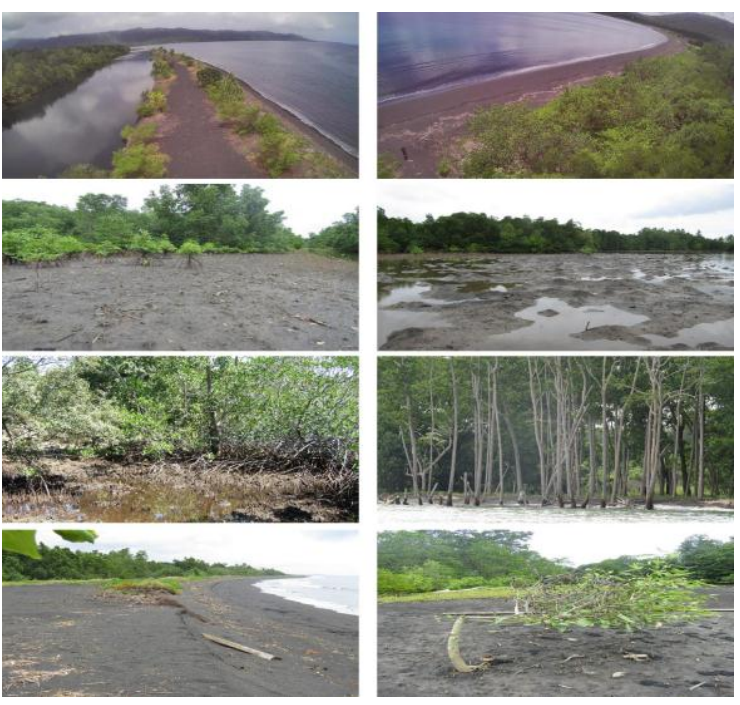

Gambar 2. Tingkat kerusakan pesisir Desa Simau

- Tahapan Dialog Bersama

Dari hasil observasi yang dilakukan oleh Tim pengabdian, maka langkah awal yang dilakukan dalam program pengabdian yaitu dialog bersama. Kegiatan dialog yang dilakukan melibatkan berbagi Instansi Pemerintah Kabupaten Halmahera Utara, Pemerintah Desa Simau, Masyarakat Desa Simau, Civitas Akademik Univesitas Halmahera serta Para Siswa SMA dan SMP. Kegiatan ini didukung melalui kerjasama Tim Pengabdian dengan Tim CEPF Uniera yang disponsori oleh Tim Burung Indonesia Jakarta. Dalam dialog ini dimana diberikan pengetahuan tentang fungsi dan peran serta resiko dan ancaman dari kerusakan hutan mangrove dan pencemaran jenis sampah dan sumber sampah, serta timbulnya penyakit akibat menumpuknya sampah. Kemudian untuk mencegah semua itu maka Tim pengabdian menawarkan solusi dengan merehabilitasi hutan mangrove dan teknik melestarikan dan kebersihan lingkungan dari sampah.

\section{- Tahapan Demonstrasi}

Dalam tahap ini semua peserta diubah pola pikirnya. Dengan menerapkan itu maka kesadaran dan kerjasama akan dibangun sehingga dapat melestarikan lingkungan ekosistem hutan mangrove dan pesisir yang bebas dari sampah.
Untuk mewujudkan prinspi tersebut maka Tim pengabdian melakukan demonstrasi dengan cara merehabilitasi hutan mangrove yang telah rusak dengan cara melakukan kegiatan pembibitan dan penanaman mangrove untuk menggantikan yang sudah rusak sehingga dapat menjaga keseimbangan ekosistem disekitarnya dan keindahan alam tetap lestari. Kegiatan pembibitan dan penanaman mangrove sebanyak 1000 anakan dan juga ditambahkan dengan 100 anakan bibit ketapang.

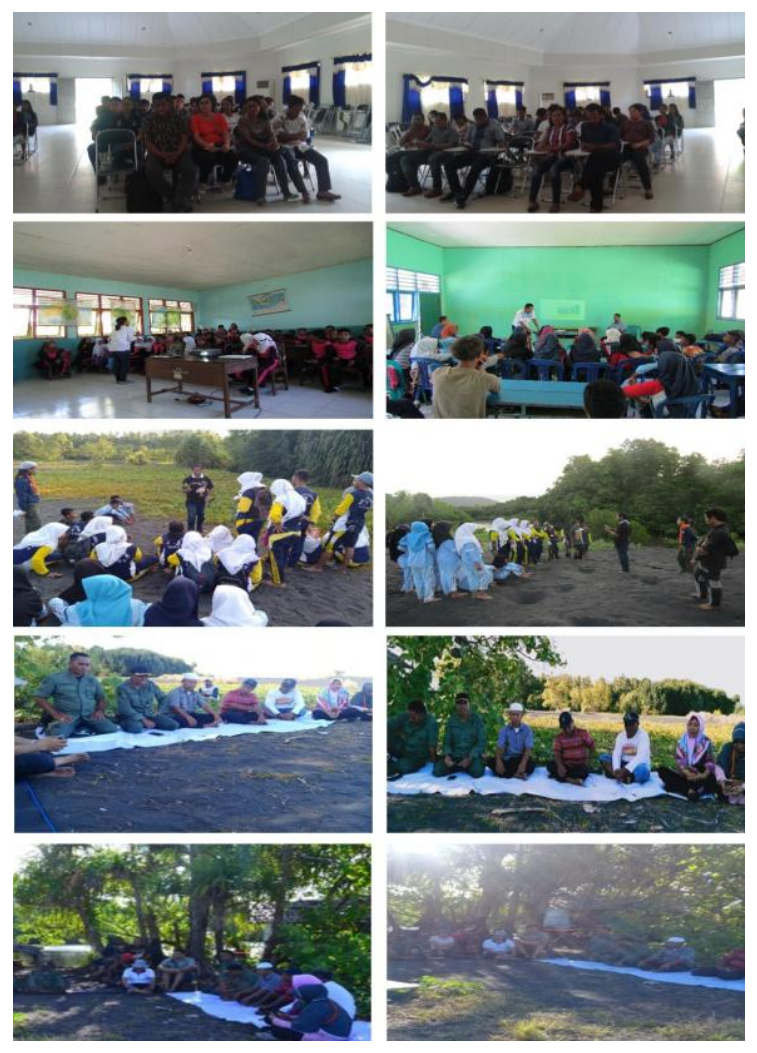

Gambar 3. Kegiatan dialog bersama

Selain itu juga masalah yang sering dihadapi yaitu pembuangan sampah oleh masyarakat yang berada dilokasi pesisir. Ekosistem mangrove ini terancam dengan aktifitas masyarakat, antara lain pembuangan sampah. Akibat oleh aktivitas masyarakat ini menyebabkan luas hutan mangrove di Desa Simau mengalami penurunan yang signifikan dari tahun ke tahun. Untuk mencegah dan mengurangi resiko ancaman tersebut maka dilakukan 
pembersihan lokasi disetiap pesisir pantai Desa Simau dengan cara mengumpulkan berbagai jenis sampah baik sampah organik maupun anorganik.

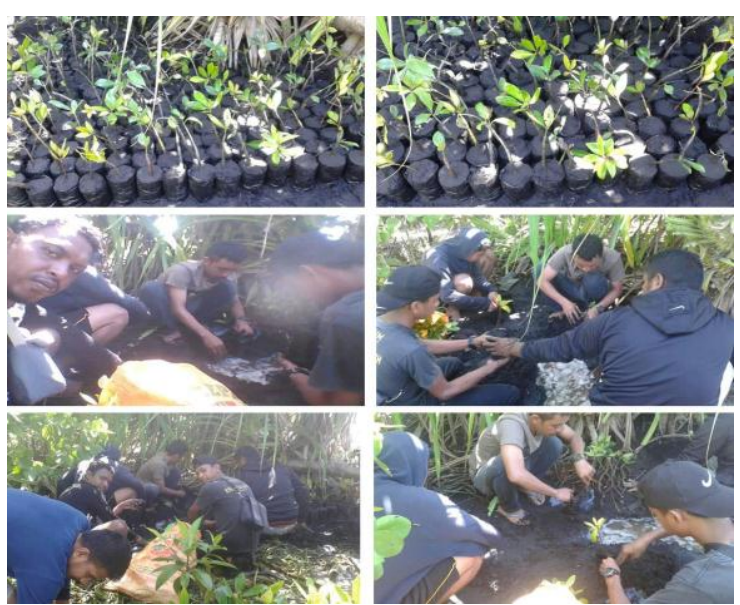

Gambar 4. Pembibitan 1000 anakan Mangrove dan 100 anakan Ketapang.

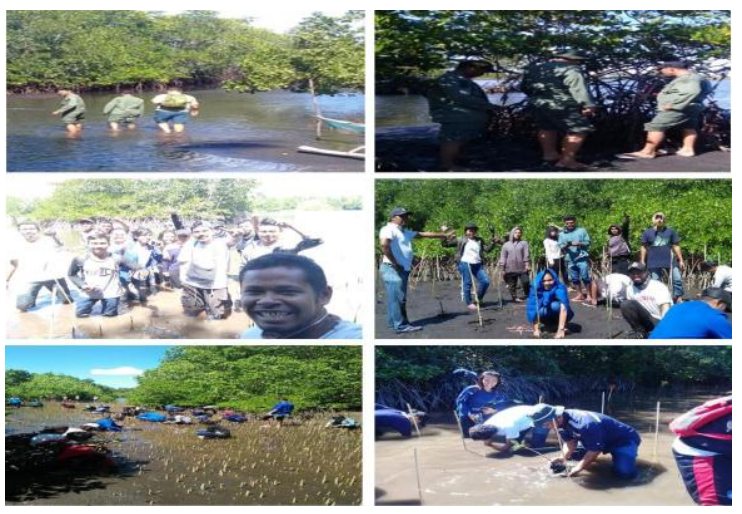

Gambar 5. Penanaman 1000 anakan Mangrove dan 100 anakan Ketapang

Adapun segala kegiatan rehabilitasi dan kebersihan lingkungan yang dilakukan dapat berjalan dengan baik dengan tujuan melestarikan hutan mangrove dan lingkungan pesisir Desa Simau dari pencemaran yang disebabkan oleh sampah.

Hasil implementasi program pengabdian dimana secara garis besar dapat dilihat berdasarkan beberapa komponen sebagai berikut:

\section{a. Keberhasilan Target Peserta}

Keberhasilan target jumlah peserta dan undangan yang terlibat dalam kegiatan pengabdian ini dapat dikatakan sangat baik. Target awal jumlah peserta sebanyak 100 orang dan dalam pelaksanaan kegiatan pengabdian, peserta yang terlibat sebanyak 147 orang (100\%). Hal ini didukung peran Instansi Pemerintah Kabupaten Halmahera Utara, Pemerintah Desa Simau, Tim CEPF Uniera, Tim Burung Indonesia, Masyarakat Desa Simau, Civitas Akademik Universitas Halmahera yang terdiri dari Dosen dan Mahasiswa, serta Mahasiswa Halmahera Pencinta Alam, serta Para Siswa dari SMA Negeri 2 Halmahera Utara dan SMP Madrasah Aliyah Muhammadiyah.

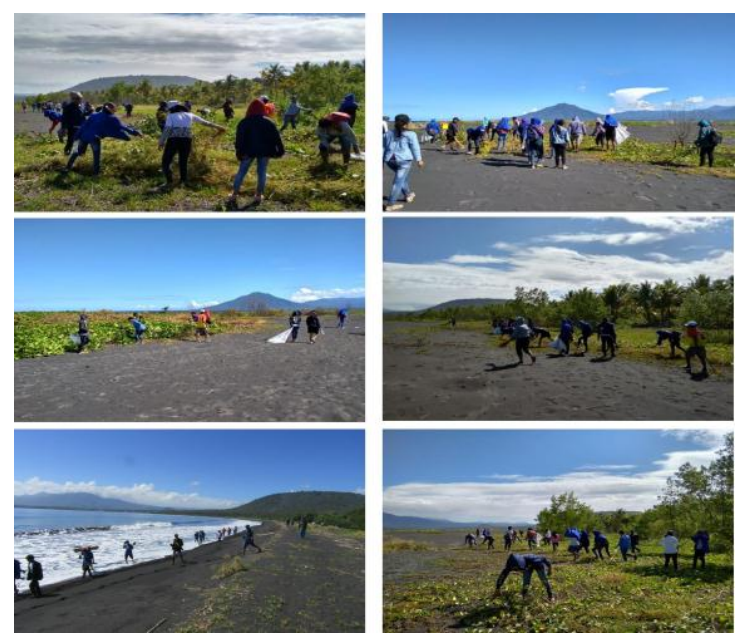

Gambar 6. Pembersihan lokasi dari pencemaran jenis-jenis sampah

\section{b. Ketercapaian Tujuan}

Ketercapaian tujuan dapat dikatakan sangat baik (100\%). Kegiatan pengabdian ini berhasil melaksanan rehabilitasi hutan mangrove dan pembersihan sampah di lingkungan pesisir. Ketercapaian tujuan ini berkat kerjasama semua pihak yang terlibat dalam melestarikan ekosistem hutan mangrove dan bebas dari pencemaran sampah.

\section{c. Ketercapaian Materi}

Ketercapaian target materi yang telah direncanakan dapat dikatakan sangat baik (100\%). Semua materi dapat disampaikan melalui dialog bersama dengan Instansi Pemerintah Kabupaten Halmahera Utara, Pemerintah Desa Simau, Civitas Akademik Universitas Halmahera yang terdiri dari Dosen dan Mahasiswa, serta Mahasiswa 
Halmahera Pencinta Alam, serta Para Siswa dari SMA Negeri 2 Halmahera Utara dan SMP Madrasah Aliyah Muhammadiyah.

Materi yang disampaikan tentang melestarikan kerusakan lingkungan ekosistem hutan mangrove melalui rehabilitasi dan kajian jenis, sumber dan berbagai penyakit yang berasal dari jenisjenis sampah yang menumpuk dilokasi kegiatan.

\section{d. Kerjasama Dalam Pengabdian}

Kerjasama dalam kegiatan pengabdian dapat dikatakan sangat baik (100\%). Hal ini didukung penggunaan metode dialog bersama dan demonstrasi untuk meningkatkan antusiasme dari Instansi Pemerintah Kabupaten Halmahera Utara, Pemerintah Desa Simau, Tim CEPF Uniera, Tim Burung Indonesia, Masyarakat Desa Simau, Civitas Akademik Universitas Halmahera yang terdiri dari Dosen dan Mahasiswa, serta Mahasiswa Halmahera Pencinta Alam, serta Para Siswa dari SMA Negeri 2 Halmahera Utara dan SMP Madrasah Aliyah Muhammadiyah.

Kerjasama yang sangat baik dimana Tim pengabdian membentuk dua kelompok yaitu kelompok pertama melakuan kegiatan pembibitan 1000 anakan mangrove dan 100 anakan ketapang, kemudian kelompok kedua membersihkan setiap lokasi hutan mangrove dari segala jenis sampah. Selanjutnya secara bersama-sama melakukan proses penanaman 1000 anakan mangrove dan 100 anakan ketapang disetiap daerah pesisir Desa Simau.

Secara keseluruhan kegiatan pengabdian kepada masyarakat tentang rehabilitasi hutan mangrove dan menjaga kebersihan lingkungan pesisir dari sampah dinilai sangat berhasil. Keberhasilan ini selain diukur dari keempat komponen di atas, juga dapat dilihat dari antusiasme semua peserta dan undangan yang terlibat mengikuti kegiatan pengabdian tersebut.
Manfaat yang dapat diperoleh setiap peserta dalam kegiatan pengabdian adalah memahami tentang pentingnya keseimbangan ekosistem hutan mangrove dan kebersihan lingkungan pesisir dari berbagai jenis sampah sehingga dapat turut serta dalam menjaga kelestarian lingkungan.

\section{KESIMPULAN}

Hasil pelaksanaan kegiatan pengabdian kepada masyarakat dapat disimpulkan metode dialog bersama dan demonstrasi yang dilakukan dalam merehabilitasi hutan mangrove dan menjaga kebersihan lingkungan pesisir dari berbagai jenis sampah turut mendapat antusiasme yang sangat baik dari semua peserta dan undangan yang ikut terlibat. Peningkatan kerjasama dari seluruh peserta dan undangan yang terlibat dalam menanggulangi masalah kerusakan hutan mangrove dan pencemaran lingkungan pesisir yang disebabkan oleh sampah berjalan dengan sangat baik.

\section{DAFTAR PUSTAKA}

Agil Al Idrus, Hadiprayitno G, Hamdi L dan Mertha IG. 2014. Invtarisasi Flora dan fauna di Kawasan Mangrove Gili Sulat untuk Pengembangan Bahan Ajar Ekologi dan Penunjang Parawisata.

Bengen D.G. 2000. Sinopsis Ekosistem dan Sumberdaya Alam Pesisir. Pusat Kajian Sumberdaya Pesisir dan Lautan. Institut Pertanian Bogor. Bogor.

Bengen D.G. 2001. Pedoman Teknis Pengenalan dan Pengelolaan Ekosistem Mangrove. Pusat Kajian Sumberdaya Pesisir dan Lautan. Institut Pertanian Bogor. Bogor.

Dahuri R, J. Rais, S.P. Ginting, M.J. Sitepu. 2001. Pengelolaan Sumber Daya Wilayah Pesisir Secara Terpadu. PT. Pradnya Paramita. Jakarta. 
Dahuri R. 2003. Keanekaragaman Hayati Laut: Aset Pembangunan Berkelanjutan Indonesia. PT. Gramedia Pustaka Utama. Jakarta.

Indrajaya D.D.S. 1992. Pengembangan Model Analisis Biaya Manfaat dengan Proses AHP dalam Pengelolaan Sumber Daya Pesisir. Jurnal Ekonomi Lingkungan.

Pical A.I. 2017. Struktur Komunitas dan Potensi Karbon Pada Vegetasi Mangrove Sonneratia alba dan Rhizophora apiculata di Perairan Pantai Kecamatan Tobelo Kabupaten
Halmahera Utara. Tesis. Program Pascasarjana Universitas Pattimura. Ambon.

Santoso N. 2000. Pola Pengawasan Ekosistem Mangrove. Makalah disampaikan pada Lokakarya Nasional Pengembangan Sistem Pengawasan Ekosistem Laut Tahun 2000. Jakarta.

Sejati. K. 2009. Pengolahan Sampah Terpadu. Yogyakarta: Kanisius.

Widyatmoko. 2002. Menghindari, Mengolah dan Menyingkirkan Sampah. : PT. Dinastindo Adiperkasa Internasional. Jakarta. 